\title{
Bryophytes diversity in Brazil
}

\author{
Denise P. Costa $^{1}$ \& Denilson F. Peralta ${ }^{2}$
}

\begin{abstract}
The bryoflora of Brazil comprises 1,524 species, 117 families, and 413 genera (11 hornworts, 633 liverworts, and 880 mosses). The most diverse families of liverworts are: Lejeuneaceae (285 species), Lepidoziaceae (48), Frullaniaceae (37), Ricciaceae (36), Plagiochilaceae (27), Radulaceae and Metzgeriaceae (26 each), Lophocoleaceae (18), Aneuraceae (15), and Calypogeiaceae (13); while, for the mosses, we have: Sphagnaceae (83 species), Fissidentaceae (65) Pottiaceae (63), Dicranaceae (54), Bryaceae and Sematophyllaceae (53 each), Orthotrichaceae and Pilotrichaceae (51 each), Calymperaceae (48), and Hypnaceae (28). These large groups account for $71 \%$ of the Brazilian bryophyte species. Lejeuneaceae and Sphagnaceae are the families with highest number of endemic taxa (54 and 60 species). The Atlantic Rainforest presents the greatest number of species $(1,337)$, followed by the Amazon Rainforest (570) and Cerrado (478). The highest number of endemic species (242) is associated with the Atlantic Rainforest, where the Dense Ombrophilous Forest concentrates $73 \%$ of the species with $62 \%$ endemism. The Southeastern region is the most diverse in number of species (1,228) and with more endemism (219). Most endangered species are restricted to the Atlantic Rainforest of southeastern Brazil, which is the diversity and endemism centre for mosses and liverworts. The information currently presented by the Brazilian List is close to the real bryophyte diversity found in the country.
\end{abstract}

Key words: hornworts, liverworts, mosses, bryoflora, South America.

\section{Resumo}

A brioflora do Brasil conta com 1.524 espécies, 117 famílias e 413 gêneros (11 antóceros, 633 hepáticas e 880 musgos). As famílias mais diversas de hepáticas são: Lejeuneaceae (285 espécies), Lepidoziaceae (48), Frullaniaceae (37), Ricciaceae (36), Plagiochilaceae (27), Radulaceae e Metzgeriaceae (26 cada), Lophocoleaceae (18), Aneuraceae (15) e Calypogeiaceae (13); e de musgos são: Sphagnaceae (83), Fissidentaceae (65), Pottiaceae (63), Dicranaceae (54), Bryaceae e Sematophyllaceae (53 cada), Orthotrichaceae e Pilotrichaceae (51 cada), Calymperaceae (48) e Hypnaceae (28), totalizando $71 \%$ das espécies de briófitas do país. Lejeuneaceae e Sphagnaceae são as famílias com maior número de endemismo (54 e 60 espécies). A Mata Atlântica apresenta o maior número de espécies (1.337), seguida pela Amazônia (570) e pelo Cerrado (478). Também apresenta o maior número de espécies endêmicas (242), com a Floresta Ombrófila Densa concentrando 73\% dos táxons e 62\% dos endemismos. A Região Sudeste é a mais diversa (1.228) e com maior endemismo (219). A maioria das espécies ameaçadas de extinção está restrita a Mata Atlântica do sudeste, que é um centro de diversidade e endemismo para musgos e hepáticas no país. As informações da Lista de Espécies da Flora do Brasil estão próximas da real diversidade de briófitas do país.

Palavras-chave: antóceros, hepáticas, musgos, brioflora, América do Sul.

\section{Introduction}

The first checklist of the Brazilian bryophytes was published by Costa \& Luizi-Ponzo (2010) treating three Divisions, or Phyla, in the country, Anthocerotophyta (hornworts), Marchantiophyta (liverworts), and Bryophyta (mosses), and represented a progress for the knowledge of the bryoflora in the country.
The first detailed publication for Anthocerotophyta and Marchantiophyta featured in the Pars Prior of Martius and Eichler Flora Brasiliensis, with the treatments prepared by Nees ab Esenbeck (1833), and, slightly later, the treatment of Bryophyta published by Hornschuch (1840) in the same encyclopaedia. At that stage 275 species of bryophytes, comprising 81 liverworts

\footnotetext{
${ }^{1}$ Rio de Janeiro Botanical Garden, R. Pacheco Leão 915, 22460-030, Rio de Janeiro, RJ, Brazil.

${ }^{2}$ Institute of Botany of São Paulo, Av. Miguel Estéfano 3687, 04301-902, São Paulo, SP, Brazil.

${ }^{3}$ Author for correspondence: denisepinheirodacosta@gmail.com
} 
and 194 mosses were recognized, representing around $18 \%$ of the currently recognized species.

Following these publications, the major advances of the knowledge of these three divisions of plants have been published in a disperse manner, in different vehicles such as checklists, regional floras, and few taxonomic revisions and descriptions of new taxa. Catalogues compiling published data were published by Yano $(1981,1984,1989,1995)$ and Costa et al. (2011). Such works summarized all citations and treatments of species recorded for Brazil, and served as the base for Gradstein \& Costa (2003) who recognized 600 species of liverworts and hornworts for Brazil, a number very close of the actually recognized to the country $(94 \%)$.

Concerning the mosses, the Brazilian Moss Guide has already been accepted for publication by The New York Botanical Garden Press. Around 800 species of mosses are recognized, a close number to what is actually recognized to the country (90\%).

Among the new studies who brought taxonomic and nomenclatural novelties after Costa \& Luizi-Ponzo (2010) we can cite: Câmara (2011) completed the World revision of Taxithelium (Pylaisiadelphaceae), Majestyk (2011) published the Neotropical revision of Daltonia (Daltoniaceae), Reiner-Drehwald (2011) new synonyms to Ceratolejeunea (Lejeuneaceae), Olson et al. (2011) accomplished the World revision of Neckeraceae, Suarez \& Schiavone (2011) revised South American Pohlia (Bryaceae), Uribe (2011) revised types of Frullania subgenus Meteoriopsis, Costa (2012) revised genus Streptopogon (Pottiaceae), Bastos (2012a,b,c,d and 2013) made new combinations and synonyms to Cheilolejeunea (Lejeuneaceae), Gradstein (2013) presented new synonyms to Omphalanthus and Aureolejeunea (Lejeuneaceae), Cano \& Jimenez (2013) revised tribe Pleuroweisiae (Pottiaceae), Söderstrom et al. (2013) added synonyms to Lophocoleaceae, Costa (2014) presented synonyms to Brazilian Pottiaceae, and Gradstein \& Ilkiu-Borges (2015) completed the World revision of the genus Odontoschisma (Cephaloziaceae).

The addition of new records to the list of bryophytes in Brazil increased the knowledge of the diversity in this group, and emphasized the importance of new records or new taxa published by Costa et al. (2008), Ilkiu-Borges \& Pereira Alvarenga (2008), IlkiuBorges \& Gradstein (2008), Bastos (2011), Bordin et al. (2011), Câmara \& Carvalho-Silva (2011), Peralta (2011), Ilkiu-Borges (2011), Câmara \& Carvalho-Silva (2012), Brito \& Ilkiu-Borges (2012a,b), Peralta \& Boas-Bastos (2012), Peralta \& Reiner-Drewald (2013), and Ayub et al. (2014).
Floristic surveys have also contributed to the bryophyte knowledge and added new records to the species list of bryophytes in Brazil, such as: Ayub et al. (2014) that recorded Riccia boliviensis Jovet-Ast and $R$. iodocheila M. Howe to the country, and $R$. squamata Nees and $R$. subplana Steph. to Rio Grande do Sul State.

This new species list of bryophytes has the main objectives add new data, including new informations and performing the correction of possible errors published in Costa \& Luizi-Ponzo (2010).

\section{Methods}

The methodology used in this study was the same adopted for the other groups of plants and fungi of Brazil, summarized in Forzza et al. (2010). Regional lists and selected databases were evaluated by the specialists who accepted the invitation to contribute online to the project website at the Jardim Botânico do Rio de Janeiro ( $<$ http://floradobrasil. jbrj.gov.br>).

Each expert was tasked with the inclusion of new records and/or the revision and modification of previously entered records, in the light of the actual knowledge for his/her speciality group, including information about life forms, substrates, vegetation types, vouchers, etc. All information was based on checked herbaria species, therefore, for a taxon ranging throughout the Brazilian states, the specialist would have seen at least one specimen per state.

The complete dataset used for the present analyses can be found as the Brazilian List of Bryophytes (see supplementary material $<$ http:// dx.doi.org/10.6084/m9.figshare.1538648> - DOI: 10.1590/2175-7860201566409).

Eight experts participated in data collection and contributed data in the following families and/ or genera (authors are listed in order of authorship): Entodontaceae (Diego K. Henriques \& Denise Pinheiro da Costa), Fissidentaceae (Juçara Bordin), Frullaniaceae (Denilson F. Peralta), Lejeuneaceae (Denise Pinheiro da Costa), Cheilolejeunea and Rectolejeunea (Cid José Passos Bastos), Lepidoziaceae (Denilson F. Peralta), Lophocoleaceae (Denilson F. Peralta), Pilotrichaceae (Denise Pinheiro da Costa), Pottiaceae (Denise Pinheiro da Costa), Sematophyllaceae (Paulo Eduardo Aguiar Saraiva Câmara), Sphagnaceae (Denise Pinheiro da Costa) and Thuidiaceae (Denise Pinheiro da Costa \& Abel Eustáquio R. Soares).

The species data for the 108 remaining families were added by the two bryophyte coordinators, Denise 
Pinheiro da Costa (liverworts and hornworts) and Denilson F. Peralta (mosses). It was also the coordinators responsibility to check and include information that was, for any reason, not complete by the end of March 2015.

\section{Results}

According to the latest dataset (see Brazilian List of Bryophytes; supplementary material $<\mathrm{http}: / /$ dx.doi.org/10.6084/m9.figshare.1538648> - DOI: $10.1590 / 2175-7860201566409)$, the bryophyte flora of Brazil comprises 1,524 species, of which 11 are hornworts, 633 liverworts and 880 mosses. This number is only $1 \%$ higher than the previous record of 1,521 species (Costa \& Luizi-Ponzo 2010) (Fig. 1). Due to recent advances in the classifications of bryophyte groups, 117 families and 413 genera are currently recognized versus 109 families and 395 genera recorded by Costa \& Luizi-Ponzo (2010).

The ten most diverse families of liverworts are: Lejeuneaceae (285 species), Lepidoziaceae (48), Frullaniaceae (37), Ricciaceae (36), Plagiochilaceae (27), Radulaceae (26), Metzgeriaceae (26), Lophocoleaceae (18), Aneuraceae (15), and Calypogeiaceae (13) (Fig. 2). For mosses, the ten most diverse families are: Sphagnaceae (83 species), Fissidentaceae (65), Pottiaceae (63), Dicranaceae (54), Bryaceae (53), Sematophyllaceae (53), Orthotrichaceae (51), Pilotrichaceae (51), Calymperaceae (48), and Hypnaceae (28) (Fig. 2).

The results in 2015 differ in relation to data presented by Costa \& Luizi-Ponzo (2010), with the liverworts of the Ricciaceae family exceeding Plagiochilaceae in number of species, Aneuraceae and Calypogeiaceae surpassing Jungermanniaceae, which now has less species (Fig. 3). For the mosses, Bryaceae, Pilotrichaceae, and Hypnaceae exceeded Fissidentaceae and Calymperaceae (Fig. 3).

Regarding the richest families of liverworts in Brazil, we highlight Lejeuneaceae (285 species) containing $45 \%$ of all species recognized for this division in Brazil, while, for the mosses, three families, Sphagnaceae (83 species), Fissidentaceae (65 species), and Pottiaceae (63 species) together total $24 \%$ of the species recognized for this division in the country.

Comparing the information published by Costa \& Luizi-Ponzo (2010) to the present list, there was a small increase in the percentage of endemic species, from $18 \%$ to $19.6 \%$. However, among the ten families of liverworts with highest number of endemic taxa, Lejeuneaceae remained the first one, with 54 species, followed by Ricciaceae (11), Metzgeriaceae (6), Lepidoziaceae (6), Frullaniaceae (5), Plagiochilaceae e Aneuraceae (2 each), Radulaceae, Lophocoleaceae, and Calypogeiaceae (1 each) (Fig. 2).

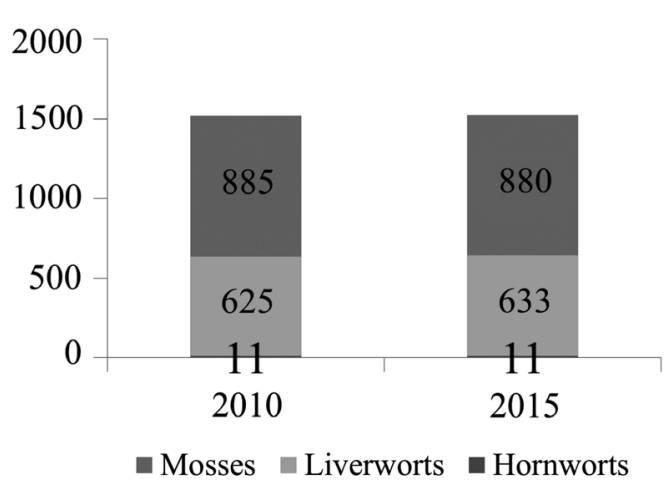

Figure 1 - Comparison between the number of species of Mosses, Liverworts and Hornworts between Costa \& Luizi-Ponzo (2010) and the 2015 list.

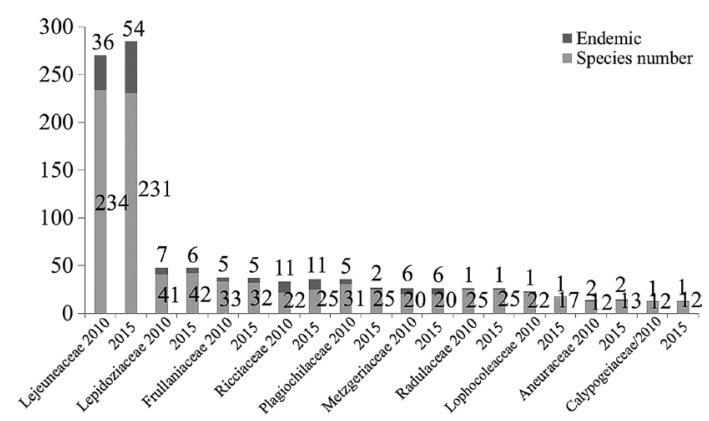

Figure 2 - Total number of species in the ten most diverse families of liverworts, comparing data from Costa \& Luizi-Ponzo (2010) and the 2015 list.

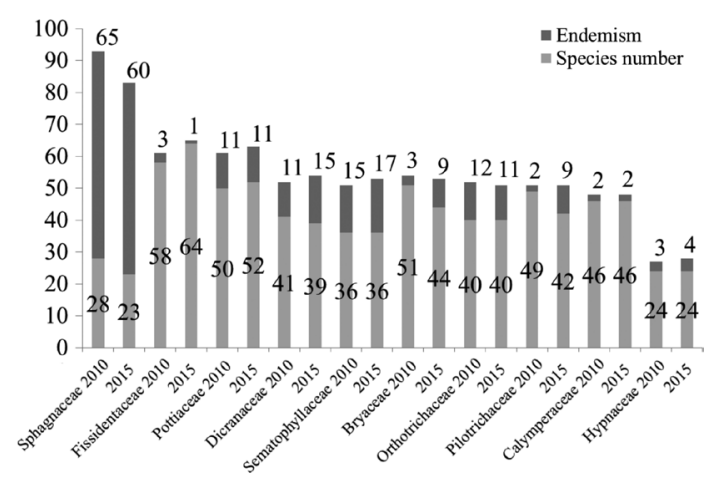

Figure 3 - Total number of species in the ten most diverse families of mosses, comparing data from Costa \& Luizi-Ponzo (2010) and the 2015 list. 
Regarding the mosses, among the ten families with the highest number of endemic taxa, Sphagnaceae remained the first one, with 60 species, followed by Sematophyllaceae (17), Dicranaceae (15), Pottiaceae and Orthotrichaceae (11 each), Bryaceae and Pilotrichaceae (9 each), Hypnaceae (4), Calymperaceae (2), and Fissidentaceae (1) (Fig. 3).

The present study recognizes 413 genera, with the 20 most diverse genera including 600 species, of which 149 species are endemic (Tab. 1). As in the previous study (Costa \& Luizi-Ponzo 2010), the three most diverse genera continue to be Sphagnum (83 species), Fissidens (65), and Lejeunea (40). However, it is noteworthy that the total number of species in Sphagnum and Lejeunea has been reduced from respectively 93 and 42 species in 2010 to 83 and 40 in 2015. Allied to this decrease, the number of endemic species in these genera also changed, and in Sphagnum falling from 65 to 60, while in Lejeunea it increased from five to six species. Other variations were recorded in the following moss genera: Fissidens, Campylopus, and Sematophyllum with respectively three, seven, and six endemic species in 2010 (from a total of 16 taxa) and had a respective increase to six, eight, and eight species (from a total of 22 taxa) in 2015. Liverwort genera such as Cololejeunea and Cheilolejeunea had a large increase in the number of species and endemic taxa, with an increase from 17 species (one endemic) in 2010 to 37 (eight endemic) in Cololejeunea, and an increase from the 16 species ( 1 endemic) previously recorded for Cheilolejeunea to 37 species (14 endemic) in 2015.

Table 1 - List of the twenty richest genera of bryophytes (10 of mosses and 10 of liverworts), with their numbers of species and endemism, comparing data from Costa \& Luizi-Ponzo (2010) and 2015.

\begin{tabular}{|c|c|c|c|c|}
\hline Genera & Species number 2015 & Endemism 2015 & Species number 2010 & Endemism 2010 \\
\hline \multicolumn{5}{|l|}{ Mosses } \\
\hline Sphagnum & 83 & 60 & 93 & 65 \\
\hline Fissidens & 65 & 6 & 61 & 3 \\
\hline Campylopus & 30 & 8 & 30 & 7 \\
\hline Syrrhopodon & 25 & 1 & 25 & 1 \\
\hline Sematophyllum & 19 & 8 & 18 & 6 \\
\hline Bryum & 19 & 5 & --- & --- \\
\hline Macromitrium & 17 & 3 & 18 & 4 \\
\hline Calymperes & 15 & 0 & 15 & 0 \\
\hline Schlotheimia & 13 & 6 & --- & --- \\
\hline Philonotis & 13 & 2 & 13 & 0 \\
\hline \multicolumn{5}{|l|}{ Liverworts } \\
\hline Lejeunea & 40 & 6 & 42 & 5 \\
\hline Cololejeunea $* * *$ & 37 & 8 & 17 & 1 \\
\hline Cheilolejeunea & 37 & 14 & 16 & 1 \\
\hline Frullania & 37 & 5 & 38 & 5 \\
\hline Riccia & 35 & 11 & 32 & 11 \\
\hline Plagiochila & 27 & 2 & 36 & 5 \\
\hline Metzgeria & 26 & 6 & 26 & 6 \\
\hline Radula & 26 & 1 & 26 & 1 \\
\hline Drepanolejeunea & 19 & 4 & 19 & 4 \\
\hline Bazzania & 17 & 1 & 17 & 1 \\
\hline Total & 600 & 149 & 516 & 126 \\
\hline
\end{tabular}

*** formerly included genus Aphanolejeunea was transferred to Cololejeunea (Pócs et al. 2014).

--- Genera not listed by Costa \& Luizi-Ponzo (2010). 
Classification changes in some genera of Lejeuneaceae meant that several species had to be transferred to other genera, with Aphanolejeunea A. Evans being subsumed into Cololejeunea (Spruce) Schiffn. (Pócs et al. 2014), (Tab. 1).

The biomes with the highest number of species continues to be the Atlantic Rainforest, with 1,337 species, followed by the Amazon Rainforest (570 species), Cerrado (478), Pantanal (176), Pampa (120), and Caatinga (96). It is worth mentioning that the bryophyte diversity for the Caatinga biome were included in the introduction of Forzza et al. (2010) but were not part of the analysis presented by Costa \& Luizi-Ponzo (2010) in the same book. The Atlantic Rainforest is the biome with the largest number of endemic species (242), followed by Cerrado (63), Amazon Rainforest (52), Pampa (16), Caatinga (8), and Pantanal (6) (Fig. 4).

The greatest diversity in the Atlantic Rainforest is found in the Ombrophilous Forest, and this vegetation type concentrates $73 \%$ of the total species and $62 \%$ of the endemism found in this biome. Ombrophilous Dense Forest and Ombrophilous Mixed Forest contain the highest richness $(1,138$ and 632 species, respectively), followed by the Amazonian Terra Firme Forest (463 species) vegetation, where 38 endemic species occur. In the Cerrado, the Gallery Forest presents a large number of species (309), with 37 endemic from this vegetation type.

Regarding the geopolitical regions, there was a significant increase in the number of new records, however the Southeast region continued to be the most diverse one, with 1,228 species in the present survey ( $v$ s. 1,205 in Costa \& Luizi-Ponzo 2010), as well as with the high number of endemism (219 taxa). The other regions also increased their representation: the South showed 843 species (vs. 796 in Costa \& Luizi-Ponzo 2010); Northeast, 689 (vs. 609); North, with 601 species (vs. 585.); and Central-west, with 496 (vs. 460) (Fig. 5).

Taking into account the diversity within the federation states, changes over the last five years did not change the position of Rio de Janeiro, São Paulo and Minas Gerais as the leading states in terms of species richness. Rio de Janeiro and São Paulo states count with 900 species each, while Minas Gerais has 766 species records (vs. 873, 840 and 687 in the previous survey), confirming the Southeast region as the one with presents the highest richness. When compared to previous data (Costa e Luizi-Ponzo 2010), the largest additions occurred in Minas Gerais state (79 species), followed by Paraná (72 species), Pernambuco (67 species), and Bahia (66 species), probably due to increased knowledge of the flora in these states which are among the ten richest in the country. The smallest additions correspond to the North region states, Amapá (two species), Acre and Roraima (five species each), and Tocantins (10 species), and the northeastern states as Piauí (seven species), Sergipe and Paraíba (12 species each), Maranhão (17 species), and Rio Grande do Norte (19 species), the latter state with the lowest diversity, adding up to only 35 species (Tab. 2).

The analysis of life-forms shows that most species that occur in Brazil have foliose habit (717). In relation to the remaining life-forms, a predominance of tuft (421 species), followed by mat (371 species), and weft (237 species) was found (Fig. 6). Regarding the type of substrate colonized by bryophytes the predominance of corticicolous (797 species), followed by terricolous ( 640 species), rupicolous ( 550 species), and epixilous (210 species). Meanwhile, 120 leaf-dwelling, or epiphyllous species belong mostly

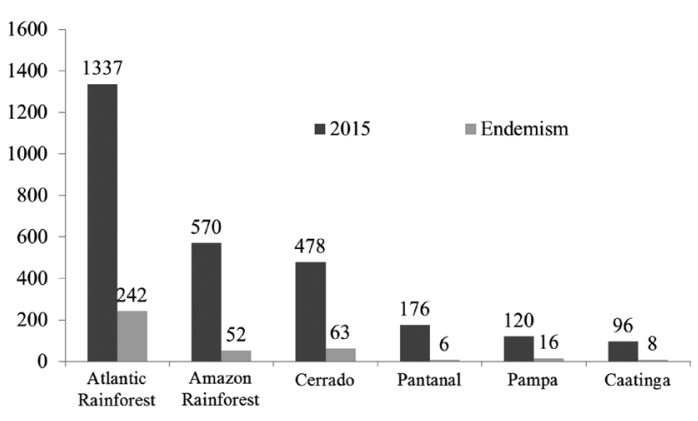

Figure 4 - Total number of bryophyte species and endemic taxa by Biome.

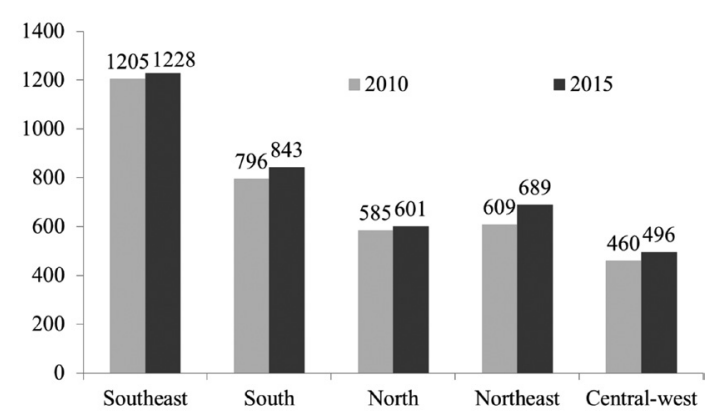

Figure 5 - Comparison of the bryophytes species number by geographic regions, comparing data from Costa \& Luizi-Ponzo (2010) and 2015. 
Table 2 - Number of species and endemism of bryophytes by state and federal district, comparing comparing data from Costa \& Luizi-Ponzo (2010) and 2015. The endemism refers to species that occur only in these states.

\begin{tabular}{|c|c|c|c|c|}
\hline States & Species number 2015 & Endemism 2015 & Species number 2010 & Endemism 2010 \\
\hline Rio de Janeiro & 900 & 17 & 873 & 24 \\
\hline São Paulo & 900 & 12 & 840 & 13 \\
\hline Minas Gerais & 766 & 16 & 687 & 17 \\
\hline Rio Grande do Sul & 569 & 6 & 526 & 10 \\
\hline Santa Catarina & 535 & 4 & 512 & 7 \\
\hline Paraná & 541 & 3 & 469 & 4 \\
\hline Bahia & 534 & 9 & 468 & 7 \\
\hline Amazonas & 457 & 23 & 440 & 20 \\
\hline Espírito Santo & 486 & 0 & 419 & 1 \\
\hline Pernambuco & 361 & 1 & 321 & 1 \\
\hline Pará & 329 & 0 & 320 & 0 \\
\hline Mato Grosso & 314 & 2 & 307 & 5 \\
\hline Goiás & 318 & 3 & 277 & 4 \\
\hline Mato Grosso do Sul & 202 & 1 & 191 & 1 \\
\hline Roraima & 193 & 2 & 188 & 1 \\
\hline Acre & 174 & 1 & 169 & 0 \\
\hline Distrito Federal & 192 & 0 & 163 & 0 \\
\hline Ceará & 187 & 0 & 158 & 0 \\
\hline Rondônia & 166 & 0 & 150 & 0 \\
\hline Amapá & 92 & 0 & 94 & 0 \\
\hline Paraíba & 94 & 0 & 82 & 0 \\
\hline Alagoas & 129 & 0 & 77 & 0 \\
\hline Maranhão & 89 & 0 & 72 & 0 \\
\hline Piauí & 50 & 1 & 57 & 1 \\
\hline Tocantins & 66 & 0 & 56 & 0 \\
\hline Sergipe & 62 & 0 & 50 & 0 \\
\hline Rio Grande do Norte & 35 & 0 & 16 & 0 \\
\hline
\end{tabular}

to the family Lejeuneaceae, especially in the genera Ceratolejeunea, Cololejeunea, Drepanolejeunea, Lejeunea, Leptolejeunea, and Prionolejeunea (Fig. 7).

Considering the three biomes with the highest number of mosses and liverworts species, the Atlantic Rainforest is the one with the greatest diversity of life forms and types of substrates, followed by the Amazon Rainforest and Cerrado (Figs. 8 and 9), where the foliose, tuft and mat life-forms predominate in conjunction with corticicolous, epixilous and terricolous substrates. In the Caatinga, Pantanal, and Pampa the commonest life-forms are tuft and weft, and the substrates are mostly corticicolous, terricolous and rupicolous (Figs. 8 e 9).

The majority of threatened species found in the Brazilian Red Book (Martinelli \& Moraes 2013) occur restricted to only one or two states in southeastern Brazil. Many of these species have reduced Occupation Area of Occurrence (AOO) or Extension Area of Occurrence (EOO), and occur in the Atlantic Rainorest, alongside all endangered species listed as threatened. 


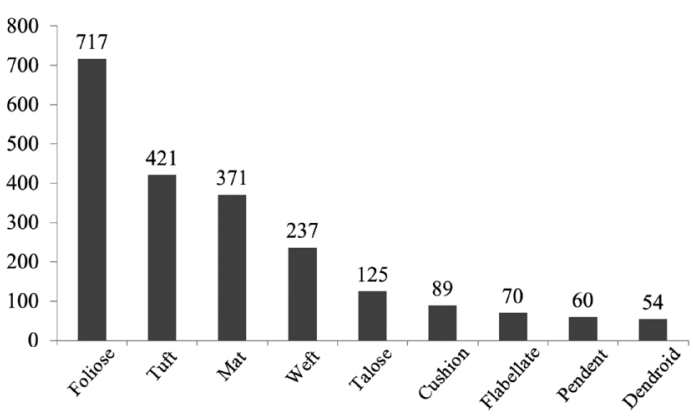

Figure 6-Total number of bryophytes species by life-form.

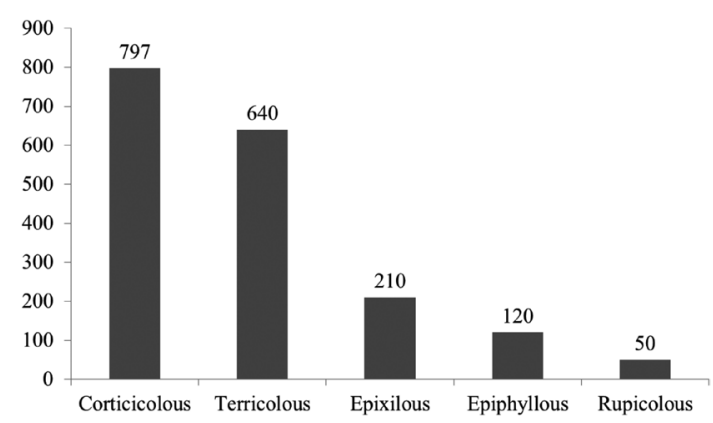

Figure 7 - Total number of bryophytes species by substrate.

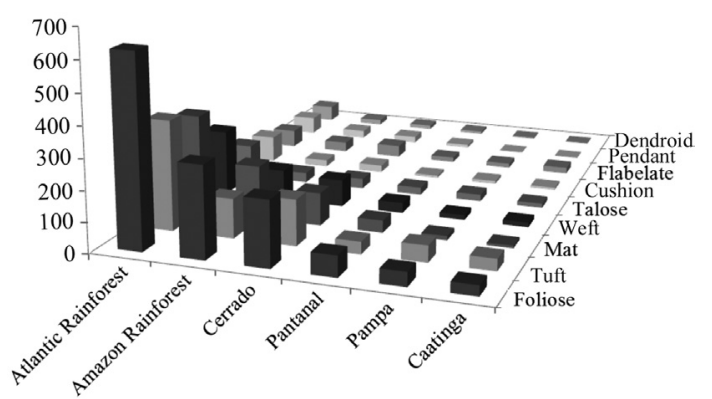

Figure 8-Species distribution by life-form and biome.

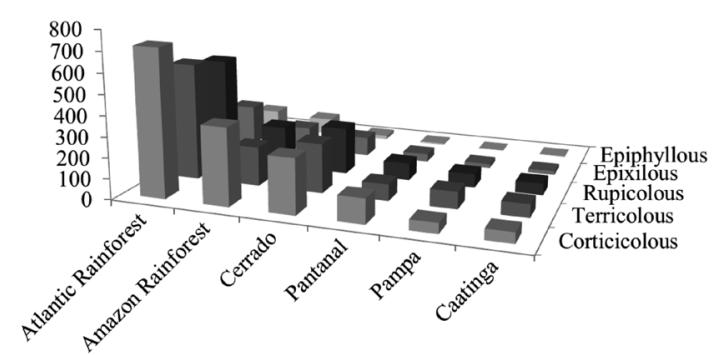

Figure 9-Species distribution by substrate and biome.

\section{Discussion}

The recognition of 1,524 species of mosses, liverworts, and hornworts for Brazil represents an advance in the knowledge of these three divisions. These figures are certainly close to the real diversity as they approach the estimates presented by Gradstein \& Costa (2003) for liverworts and hornworts (600-750 species) and Costa et al. (2011) for mosses (892 species), with an addition of only three species over what was previously recorded by Costa \& Luizi-Ponzo (2010).

The difference in species number is small however the number of families and genera recognized are consistently different, with 117 families and 413 genera versus 109 families and 395 genera listed in Costa \& Luizi-Ponzo (2010). The difference in family and genera number is due to recently published studies that focused on large, previously understudied groups including changes of circumscription at genus and family level and presenting vast synonymy. These studies clarified important gaps related to the taxonomy and geographic distribution of taxa. In the genus Sphagnum, for example, 93 species were recognized in the list of Costa \& Luizi-Ponzo (2010), while only 83 are recognized in the present list. This genus is currently under revision (Costa, unpublished).

On the other hand, many groups still are in need of detailed study, not only for species circumscription, but also to fully understand the geographic distribution of their taxa. These include liverworts such as Bazzania, Frullania, Lejeunea p.p., Plagiochila p.p., and Riccardia and moss genera Callicostella, Cyclodictyon, Hyophila, Macromitrium, Mittenothamnium, Schlotheimia, and Sematophyllum p.p.. These groups lack recent taxonomic treatments including identification keys, descriptions, and illustrations. Some of these genera are already under study, but the data are not yet available to be included in the present work. It is probable that the number of species featured for these groups is underestimated in our list.

The Atlantic Rainforest, the biome with the highest number of species including the largest number of endemic and endangered species, is recognized as one of the hotspots in the planet (Mittermeier et al. 1998, 2004), and has already been pointed out as one of the main centres of diversity and endemism for mosses and liverworts 
in the Brazil (Gradstein \& Costa 2003; Costa et al. 2011). This high diversity is attributed to different environmental conditions occurring in mountainous tropical areas (humid climate with rains distributed throughout the year; fog in the mountains; ample variation of average temperatures from the lowland to the high mountains), favouring a greater number of microhabitats, high rainfall, and topographic complexity (mountain ranges with cloud forest in the Altitude Grasslands; shoreline fringed by sandy beaches, rocky shores, salt marshes and mangroves), which leads consequently to greater floristic diversity (Pócs 1982).

\section{Conclusions}

We believe that the information compiled for this paper approaches closely the real diversity of bryophytes in the country. However, gaps are still recognized in regions that need increased collection efforts and remain insufficiently sampled. Further studies developed in these regions will certainly yield new records possibly new species of mosses, hornworts and liverworts for the Brazilian Flora.

\section{References}

Ayub, D.M.; Costa, D.P. \& Santos, R.P. 2014. Additions to the Ricciaceae flora of Rio Grande do Sul, including two remarkable records for the Brazilian liverwort flora. Phytotaxa 161: 294-300.

Bastos, C.J.P. 2011. Cheilolejeunea ornata (Lejeuneaceae), a new species from Brazilian Atlantic Forest. Journal of Bryology 33: 86-88.

Bastos, C.J.P. 2012a. Nomenclatural notes on the genus Rectolejeunea A. Evans (Lejeuneaceae, Marchantiophyta). Journal of Bryology 34: 144-145.

Bastos, C.J.P. 2012b. New combinations and synonyms in Cheilolejeunea (Spruce) Schiffn. (Lejeuneaceae, Marchantiophyta). Journal of Bryology 34: 312-315.

Bastos, C.J.P. 2012c. Synonymy and notes on the occurrence of Cheilolejeunea intertexta (Lindenb.) Steph. (Lejeuneaceae, Marchantiophyta) in Neotropics. Journal of Bryology 34: 66-67.

Bastos, C.J.P. 2012d. Type studies on Cheilolejeunea (Spruce) Schiffn. (Lejeuneaceae): Brazilian species described by Stephani. Journal of Bryology 34: 315-318.

Bastos, C.J.P. 2013. Cheilolejeunea. In: Lista de Espécies da Flora do Brasil. Jardim Botânico do Rio de Janeiro. Available in (http://floradobrasil.jbrj.gov.br/jabot/ floradobrasil/ FB126233). Access on 6 May 2015.

Bastos, C.J.P. \& Gradstein, S.R. 2006. Two new species of Cheilolejeunea (Spruce) Schiffn. (Lejeuneaceae) from Brazil: C. lacerata sp. nov. and C. rupestris sp. nov. Journal of Bryology 28: 133-138.
Bordin, J.; Pursell, R.A. \& Yano. O. 2011. Fissidens pseudoplurisetus sp. nov. (Fissidentaceae, subgenus Aloma), from the Atlantic forest, Brazil. The Bryologist 114: 785-789.

Brito, E.S. \& Ilkiu-Borges, A.L. 2012a. A new species of Ceratolejeunea Jack \& Steph. (Lejeuneaceae, Jungermanniopsida) from a remnant of Amazonian forest in Maranhão, Brazil. Nova Hedwigia 95: 423-428.

Brito, E.S. \& Ilkiu-Borges, A.L. 2012b. Primeiro registro de Cololejeunea panamensis para a America do Sul. Rodriguésia 63: 1-3.

Câmara, P.E.A.S. 2011. A review of Taxithelium (Pylaisiadelphaceae). Systematic Botany 36: 824-835.

Câmara, P.E.A.S. \& Carvalho-Silva, M. 2011. Taxithelium juruense (Broth.) Broth. (Pylaisiadelphaceae) an endangered Brazilian endemic, with notes on the genus Taxithelium for Brazil. Acta Botanica Brasilica 25: 198-202.

Câmara, P.E.A.S. \& Carvalho-Silva, M. 2012. A new species of Taxithelium (Pylaisiadelphaceae) from Brazil. The Bryologist 115: 444-448.

Cano, M.J. \& Jimenez, J.A. 2013. A taxonomic revision of the tribe Pleuroweisiae (Pottiaceae, Bryophyta) in South America. Phytotaxa 143: 1-42.

Costa, D.P. 2012. Validation of the new species of Streptopogon (Pottiaceae, Bryophyta) and a synopsis of the genus for Brazil. Systematic Botany 37: 583-586.

Costa, D.P. 2014. New synonyms for South American/ Brazilian Pottiaceae (Bryophyta). Phytotaxa 167: 137-140.

Costa, D.P.; Pôrto, K.C.; Luizi-Ponzo, A.P.; Ilkiu-Borges, A.L.; Bastos, C.J.P.; Câmara, P.E.A.S.; Peralta, D.F.; Bôas-Bastos, S.B.V.; Imbassahy, C.A.A.; Henriques, D.K.; Gomes, H.C.S.; Rocha, L.M.; Santos, N.D.; Siviero, T.S.; Vaz-Imbassahy, T.F. \& Churchill, S.P. 2011. Synopsis of the Brazilian moss flora: checklist, distribution and conservation. Nova Hedwigia 93: 277-334.

Costa, D.P. \& Luizi-Ponzo, A.P. 2010. As briófitas do Brasil. In: Forzza et al. (orgs.). Catálogo de Plantas e Fungos do Brasil. Vol.1. Instituto de Pesquisas Jardim Botânico do Rio de Janeiro, Rio de Janeiro. Pp. 61-68.

Costa, D.P.; Pôrto, K.C.; Luizi-Ponzo, A.P.; Ilkiu-Borges, A.L.; Bastos, C.J.P.; Câmara, P.E.A.S.; Peralta, D.F.; Bôas-Bastos, S.B.V.; Imbassahy, C.A.A.; Henriques, D.K.; Gomes, H.C.S.; Rocha, L.M.; Santos, N.D.; Siviero, T.S.; Vaz-Imbassahy, T.F. \& Churchill, S.P. 2011. Synopsis of the Brazilian moss flora: checklist, distribution and conservation. Nova Hedwigia 93: 277-334.

Costa, D.P.; Santos, N.D. \& Váña, J. 2008. A New Species of Cylindrocolea (Cephaloziellaceae) from Brazil. The Bryologist 111: 667-669. 
Gradstein, S.R. 2013. Notes on Early land plants today 22. New combinations and new synonymy in Omphalanthus and Aureolejeunea (Lejeuneaceae, Marchantiophyta). Phytotaxa 76: 45-47.

Gradstein, S.R. \& Costa, D.P. 2003. The Hepaticae and Anthocerotae of Brazil. Memoirs of The New York Botanical Garden 87: 1-318.

Forzza, R.C.; Baumgratz, J.F.A.; Bicudo, C.E.M.; Canhos, D.A.L.; Carvalho Jr., A.A.; Costa, A.F.; Costa, D.P.; Hopkins, M.; Leitman, P.M.; Lohmann, L.G.; Maia, L.C.; Martinelli, G.; Menezes, M.; Morim, M.P.; Nadruz-Coelho, M.A.; Peixoto, A.L.; Pirani, J.R.; Prado, J.; Queiroz, L.P.; Souza, V.C.; Stehmann, J.R.; Sylvestre, L.; Walter, B.M.T. \& Zappi, D. (eds.). 2010. Catálogo de plantas e fungos do Brasil. 2 vols. Andrea Jakobsson Estúdio / Jardim Botânico do Rio de Janeiro, Rio de Janeiro. 1699p.

Gradstein, S.R. \& Ilkiu-Borges, A.L. 2015. A taxonomic revision of the genus Odontoschisma (Marchantiophyta, Cephaloziaceae). Nova Hedwigia 99: 15-100.

Hornschuch, C.F. 1840. Musci. In: C.F.P. Martius (ed.). Flora Brasiliensis seu enumeratio plantarum in Brasilia hactenus detectarum quas suis aliorumque botanicorum studiis descriptas et methodo naturali digestas partim icone illustratas. Stuttgartiae et Turbingae, J.G. Cottal. Vol. 1, part 2, pp. 1-100.

Ilkiu-Borges, A.L. 2011. On Pycnolejeunea gadsteinnii (Lejeuneaceae) a new species from Brazil. Boletim do Instituto de Botânica de São Paulo 21: 1-4.

Ilkiu-Borges, A.L. \& Gradstein, S.R. 2008. A new species of Cheilolejeunea (Spruce) Schiffn. (Lejeuneaceae) from Cerro de la Neblina, Venezuela. Nova Hedwigia 87: 521-528.

Ilkiu-Borges, A.L. \& Pereira-Alvarenga, L.D. 2008. On Ceratolejeunea atlantica, a new species of Lejeuneaceae (Jungermanniopsida) from Brazil. Nova Hedwigia 86: 237-241.

Majestyk, P. 2011. A taxonomic treatment of Daltonia (Musci: Daltoniaceae) in the Americas. Journal of the Botanical Research Institute of Texas 5: 553-575.

Martinelli, G. \& Moraes, M.A. (orgs.) 2013. Livro vermelho da flora do Brasil. Andrea Jakobsson \& Instituto de Pesquisas Jardim Botânico do Rio de Janeiro, Rio de Janeiro. 1100p.

Mittermeier, R.A.; Myers, N.; Thomsen, J.B.; Fonseca, G.A.B. da \& Olivieri, S. 1998. Biodiversity hotspots and major tropical wilderness areas: approaches to setting conservation priorities. Conservation Biology 12: 516-520.

Mittermeier, R.A.; Robles-Gil, P.R.; Hoffmann, M.; Pilgrim, J.; Brooks, T.; Mittermeier, C.G.; Lamoreux, J. \& Fonseca, G.A.B. 2004. Hotspots revisited. Earth's biologically richest and most endangered terrestrial ecoregions. CEMEX, Washington, DC. 392p.
Nees ab Esenbeck, C.G. 1833. Hepaticae. In: Martius, C.F.P. (ed.). Flora Brasiliensis seu enumeratio plantarum in Brasilia tam sua ponte quam accedente cultura provenientium quas in itineré auspicius Maximilianai Joseph I. bavariae regis annis 18171820 peracto collegit, partim descript. Stuttgartiae et Turbingae, J.G. Cottal. Vol. 1, pars prior, pp. 293-390.

Olsson, S.; Enroth, J.; Buchbender, V.; Hedenäs, L.; Huttunen, S. \& Quandt, D. 2011. Neckera and Thamnobryum (Neckeraceae, Bryopsida) paraphyletic assemblages. Taxon 60: 36-50.

Peralta, D.F. 2011. Ocorrência do gênero Conostomum Sw. (Bartramiaceae) no Brasil. Acta Botanica Brasilica 25: 935-936.

Peralta, D.F. \& Boas-Bastos, S.V. 2012. Occurrence of the genus Pterobryopsis M. Fleisch. (Pterobryaceae) in Brazil. Revista Brasileira de Botânica 35: 125-127.

Peralta, D.F. \& Reiner-Drewald, M.E. 2013. Cheilolejeunea laciniata (Lejeuneaceae, Marchantiophyta), a new species from Southeastern Brazil. The Bryologist 116: 53-57.

Pócs, T. 1982. Tropical Forest Bryophytes. In: Smith, A.J.E. Bryophyte Ecology. Chapman and Hall, New York. Pp. 59-104.

Pócs, T.; Bernercker, A. \& Tixier, P. 2014. Synopsis and key to species of Neotropical Cololejeunea (Lejeuneaceae). Acta Botanica Hungarica 562: 185-226.

Reiner-Drehwald, M.E. 2011. Studies on Neotropical Lejeuneaceae (Jungermanniopsida). New synonyms and Ceratolejeunea temnantha (Spruce) comb. nov. Cryptogamie, Bryologie 32: 95-100.

Soderstrom, L.; Váňa, J.; Crandall-Stotler, B.; Stotler, R.; Hagborg, A. \& Konrat, M. 2013. Notes on land plants today 43. New combinations in Lophocoleaceae (Marchantiophyta) Phytotaxa 122: 18-32.

Suarez, G.M. \& Schiavone, M.S. 2011. Pohlia Hedw section Pohlia (Bryaceae) in Central and South America. Nova Hedwigia 92: 453-477.

Uribe-M, J. 2011. Type studies on Frullania subgenus Meteoriopsis. VI. Subgeneneric affiliation of selected Asiatic species previously assigned to subg. Meteoriopsis. Caldasia 33: 67-77.

Yano, O. 1981. Checklist of Brazilian mosses. The Journal Hattori Botanical Laboratory 50: 279-456.

Yano, O. 1984. Checklist of Brazilian liverworts and hornworts. The Journal Hattori Botanical Laboratory 56: 481-548.

Yano, O. 1989. An additional checklist of Brazilian bryophytes. The Journal Hattori Botanical Laboratory 66: 373-434.

Yano, O. 1995. A new additional annoted checklist of Brazilian bryophytes. The Journal Hattori Botanical Laboratory 78: 137-182. 
